\title{
Expression of factors involved in regulation of DNA mismatch repair- and apoptosis pathways in ovarian cancer patients
}

\author{
VERENA MATERNA ${ }^{1}$, PAWEL SUROWIAK ${ }^{1-3}$, EWA MARKWITZ ${ }^{4}$, MAREK SPACZYNSKI $^{4}$, \\ MALGORZATA DRAG-ZALESINSKA ${ }^{2}$, MACIEJ ZABEL ${ }^{2,5}$ and HERMANN LAGE ${ }^{1}$ \\ ${ }^{1}$ Institute of Pathology, Charité Campus Mitte, Charitéplatz 1, D-10117 Berlin, Germany; ${ }^{2}$ Department of Histology and \\ Embryology, Wroclaw Medical University, Chalubinskiego 6a, 50-368 Wroclaw; ${ }^{3}$ Lower Silesian Centre of Oncology, \\ pl. Hirszfelda 12, 53-413 Wroclaw; ${ }^{4}$ Department of Obstetrics and Gynecology, Poznan University of Medical \\ Sciences, ul. Polna 33, 60-535 Poznan; ${ }^{5}$ Department of Histology and Embryology, Poznan University \\ of Medical Sciences, Swiecickiego 6, 60-781 Poznan, Poland
}

Received September 19, 2006; Accepted October 26, 2006

\begin{abstract}
A major obstacle in treatment of ovarian cancer is intrinsic or acquired drug resistance causing failure of chemotherapy followed by a poor clinical outcome. Drug resistance of ovarian carcinoma can be caused by dysregulation of cellular factors involved in regulation of apoptosis and DNA repair pathways. In this study, 73 ovarian carcinoma specimens obtained before and after chemotherapy were analysed by immunohistochemistry for expression of seven proteins playing an important role in regulation of DNA mismatch repair and apoptosis. The prognostic significance of these proteins in the meaning of overall and progression-free survival was evaluated in univariate and multivariate analysis. $\mathrm{Bcl}-\mathrm{x}_{\mathrm{L}}, \mathrm{hMSH} 2$, caspase-3, p21 and p53 displayed prognostic importance in univariate analysis. Furthermore, it was demonstrated that caspase- 3 and p 21 were also independent prognostic markers for both, overall and progression-free survival. In conclusion, these data indicate that analysis of proteins involved in DNA mismatch repair and apoptosis can be useful for prediction of clinical outcome in ovarian carcinoma patients.
\end{abstract}

\section{Introduction}

Ovarian cancer is the fith most common malignancy and ranks fourth in causing death due to cancer among women (1). The main reason for these unfavorable circumstances is the late diagnosis at stage III or IV due to absence of clinical symptoms. Although the application of chemotherapy based on platinum-containing drugs and paclitaxel prolongs survival (2), most of the patients with advanced disease die

Correspondence to: Dr Hermann Lage, Charité Campus Mitte, Institute of Pathology, Charitéplatz 1, D-10117 Berlin, Germany E-mail: hermann.lage@charite.de

Key words: ovarian carcinoma, drug resistance, apoptosis, mismatch repair, chemotherapy after the development of chemoresistant recurrent tumors. The cellular stress response on chemotherapeutic drugs is dependent on a cascade of proteins leading to cell cycle arrest, DNA damage repair and/or apoptosis. Changes in these elementary processes can lead to chemoresistance in tumor cells and are therefore needed to be investigated thoroughly.

The DNA mismatch repair (MMR) system detects nucleotide mismatches, small insertions and deletions, and different types of drug-induced DNA-adducts. Cells that have lost their MMR activity are impaired to detect and react to these types of DNA damage resulting in genomic instability and loss of essential apoptotic response. Previous studies using cancer cell lines have indicated a correlation between MMR status and sensitivity to certain classes of chemotherapeutic drugs including the observation, that MMR-deficient cells (mostly investigated proteins: hMLH1 and hMSH2) are resistant to platinum-containing drugs such as cisplatin and carboplatin (3). However, previous data obtained by immunohistochemical analyses of hMLH1 and hMSH2 in ovarian cancer patients are contradictory (4-7).

It has been shown that the TP53 tumor suppressor gene is the most frequently mutated gene in human cancers (8). Mutated p53 protein is resistant to degradation and has a prolonged half-life which allows its detection by immunohistochemistry (9). It has also been described that the efficacy of cytostatic drugs requires functional p53 protein and that loss of its function enhances resistance to these drugs because of inefficient induction of apoptosis (10-12). Furthermore, it has been suggested that the combined inactivation of p53 and of the MMR system is required for the development of cisplatin resistance, whereas p53 plays a more important role than the failure of the MMR system alone (13). In the case of DNA damage, p53 induces the expression of several downstream genes including $\mathrm{p} 21^{\text {(WAF1/CIP1) }}$ resulting in cell-cycle arrest during the $\mathrm{G} 1$ to $\mathrm{S}$ transition by inhibition of cyclin-dependent kinases $(14,15)$. p21 is thought to be a major downstream effector of p53 and its protein expression has been detected in cells expressing wild-type p53, but not in those with nonfunctional p53 protein (15). Moreover, p53-independent 
pathways may also lead to an increase of p21 expression (16-18). Although p53 and p21 expression were studied extensively in ovarian carcinoma patients (19-23), the importance of p53 and p21 for the clinical outcome is not certain, because the results are conflicting (24). The p53-related protein p63 plays a key role in regulating epithelial proliferation and differentiation programs $(25,26)$. It has been reported that p63 overexpression can mimic p53 activities such as DNA binding, activation of transcription, and induction of apoptosis $(26,27)$, and may compromise the effectiveness of p53 gene therapy (28).

Caspases are highly specific proteases synthesized as zymogens and activated by cleavage generating large and small subunits of the mature enzyme. They are divided into two groups, upstream or initiator caspases and downstream or executioner caspases. Caspases collaborate in the proteolytic cascade by activating themselves and each other resulting in membrane blebbing, chromatin condensation, and DNA fragmentation, the hallmark changes in apoptotic processes (29). The executioner caspase-3 (also known as CPP32, Yama and apopain) is considered to be the central protein in triggering apoptosis (30) and has also been reported to be involved in drug resistance in human cancer cell lines (31-33). Scarce data are available examining the possible prognostic relevance of caspase-3 in cancer patients (34-36).

Proteins of the BCL2 family of genes are known to modulate the programmed cell death and are also involved in development, tissue homeostasis and pathogenesis of different diseases such as cancer, viral infections, neurodegenerative disorders, and autoimmune disease (37). The anti-apoptotic protein $\mathrm{Bcl}-\mathrm{x}_{\mathrm{L}}$, a functional and structural homologue of $\mathrm{Bcl}-2$, is supposed to be responsible for modulating resistance to chemotherapy-induced apoptosis (38). Nethertheless, the significance of different $\mathrm{Bcl}-\mathrm{x}_{\mathrm{L}}$ expression levels in the context of affecting chemoresistance and the prognostic relevance in cancer patients are still ambiguous (38-41).

In this study, we examined the protein expression of the mismatch repair components hMLH1 and hMSH2, the apoptotic cascade enzyme caspase-3, the anti-apoptotic Bcl- $\mathrm{X}_{\mathrm{L}}$, and the tumor suppressor genes p53 and p21, and the p53related p63 protein in ovarian cancer patients. Analyses were performed to evaluate the prognostic significance of each of these proteins alone or in combination for patient's survival.

\section{Materials and methods}

Patients and histology. Immunohistochemical examination was performed retrospectively on tissue samples taken for routine diagnostic purposes. Forty-three patients operated in 1999-2002 due to ovarian carcinoma in the Department of Obstetrics and Gynecology (Poznan University of Medical Sciences, Poland) were studied. The study was approved by an Institutional Review Board (IRB) and the patients gave their informed consent before their inclusion into the study. The cases were selected based on availability of tissue and were not stratified for known preoperative or pathological prognostic factors. Following the first-look laparatomy all the patients were subjected to chemotherapy using platinumbased schemes. Only the FIGO I and FIGO II patients
Table I. Patient and tumor characteristics.

\begin{tabular}{|c|c|}
\hline Characteristics & No. $(\%)^{\mathrm{b}}$ \\
\hline All patients & $43(100)$ \\
\hline First-look laparatomy (FLL) & $43(100)$ \\
\hline Secondary cytoreduction (SCR) & $36 \quad(84)$ \\
\hline No tumor cells at time of SCR & $6 \quad(14)$ \\
\hline \multicolumn{2}{|l|}{ Age (mean 51.0) $)^{\mathrm{a}}$} \\
\hline$\leq 50$ & $(47)$ \\
\hline$>50$ & $23 \quad(53)$ \\
\hline
\end{tabular}

Grade $^{\mathrm{a}}$

1

2

3

\section{$\mathrm{FIGO}^{\mathrm{a}}$}

I 1

II

III

Histology $\mathrm{y}^{\mathrm{a}}$

Serosum

Others

Clinical response ${ }^{\mathrm{c}}$

Complete response $16 \quad$ (37)

Stable disease $\quad 5$

Progressive disease

Chemotherapy (in total)

Cisplatin/paclitaxel

Cisplatin/cyclophosphamide/adriblastin

Cisplatin/cyclophosphamide/paclitaxel

Cisplatin/cyclophosphamide/paclitaxel/

adriblastin

Carboplatin/paclitaxel

${ }^{\text {aData }}$ are given to first surgical treatment/diagnosis implemented. ${ }^{b}$ Differences in the sum to $100 \%$ in groups are due to rounding. ${ }^{\mathrm{c}}$ Clinical response to first-line chemotherapy was defined according to the criteria suggested by RECIST (Response Evaluation Criteria in Solid Tumors) (42).

achieved optimal cytoreduction after initial surgery. Thirtysix patients from the same group were subjected also to the second-look operation. In seven cases no second-look procedure was performed due to advancement of the disease. In six cases no tumor cells were detected in the material originating from the secondary cytoreduction (Table I). The patients were monitored by periodic medical check-ups, CA-125 serum levels, ultrasonographic and radiological examinations. Tissue samples were fixed in $10 \%$ buffered formalin and, then, embedded in paraffin. In each case, hematoxylin and eosin stained preparations were subjected to histopathological evaluation by two pathologists. The stage of 
Table II. Procedure for expression evaluation using IRS (immunoreactive score) (45).

\begin{tabular}{lclc}
\hline $\begin{array}{l}\text { Percentage of } \\
\text { positive cells }\end{array}$ & Points & $\begin{array}{c}\text { Intensity of } \\
\text { reaction }\end{array}$ & Points \\
\hline No positive cells & 0 & No reaction & 0 \\
$<10 \%$ positive cells & 1 & Weak color reaction & 1 \\
10-50\% positive cells & 2 & Moderate intensity & 2 \\
$51-80 \%$ positive cells & 3 & Intense reaction & 3 \\
$>80 \%$ positive cells & 4 & & \\
\hline
\end{tabular}

the tumors was assessed according to the International Federation of Gynecology and Obsterics (43). Tumors were graded according to the Silverberg grading system (44).

Immunohistochemistry. Formalin-fixed paraffin-embedded tissue was freshly cut $(4 \mu \mathrm{m})$. The sections were mounted on Superfrost slides (Menzel Glaeser, Braunschweig, Germany), dewaxed with xylene, and gradually rehydrated. Activity of endogenous peroxidase was blocked by $30 \mathrm{~min}$ incubation in $1 \% \mathrm{H}_{2} \mathrm{O}_{2}$. Detection of p53, p63, p21, hMLH1, hMSH2 and $\mathrm{Bcl}-\mathrm{x}_{\mathrm{L}}$ expression was preceded by 10 min exposure to boiling Antigen Retrieval Solution (DakoCytomation, Glostrup, Denmark), in the case of p63 Antigen Retrieval Solution High $\mathrm{pH}$, in a microwave oven.

Immunohistochemical reactions were performed using the following antibodies: anti-p53 mAb (mouse), clone DO-7 (DakoCytomation), dilution 1:200; anti-63 mAb (mouse), clone 4A4 (DakoCytomation), dilution 1:100; anti-p21 mAb (mouse), clone SX118 (DakoCytomation), dilution 1:100; anti-hMLH1 mAb (mouse), clone G168-15 (BD Bioscience Pharmingen, San Diego, CA, USA), dilution 1:100; anti-hMSH2 mAb (mouse), clone GB12 (BD Bioscience Pharmingen, San Diego, CA, USA), dilution 1:100; anti-Bcl- $\mathrm{x}_{\mathrm{L}}$ polyclonal Ab (rabbit) (Santa Cruz Biotechnology, Santa Cruz, CA, USA), dilution 1:100; anti-caspase-3 (active form) mAb, clone Ab-4 (Oncogene Research Products, Darmstadt, Germany), dilution 1:400.

Tested sections were incubated with the antibodies in Antibody Diluent, Background Reducing (DakoCytomation) at RT for $1 \mathrm{~h}$. Subsequently, incubations were performed with biotinylated antibodies (15 min, RT) and with streptavidinbiotinylated peroxidase complex $(15 \mathrm{~min}, \mathrm{RT})\left(\mathrm{LSAB}^{+}\right.$, HRP, DakoCytomation). NovaRed (Vector Laboratories, Peterborough, UK) was used as a chromogen (10 min, RT). All the sections were counterstained with Meyer's hematoxylin.

Negative controls were included in which specific antibody was substituted by the Primary Mouse Negative Control (DakoCytomation). In the case of p63, control reactions were performed on 6 sections of healthy human breast (from the Archive of Department of Histology and Embryology, Wroclaw Medical University, Poland).

Intensity of the immunohistochemical reactions was appraised using a semi-quantitative immunoreactive score, in which intensity of the reaction and percentage of positive cells were estimated (Table II). Final result represented a product of scores given for individual traits and ranged between 0 and 12 (45). Intensity of immunohistochemical reactions

\section{A}
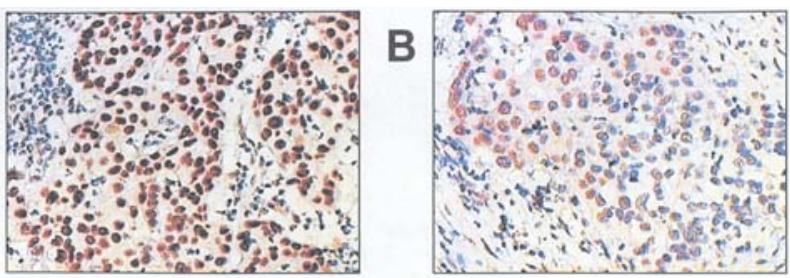

c
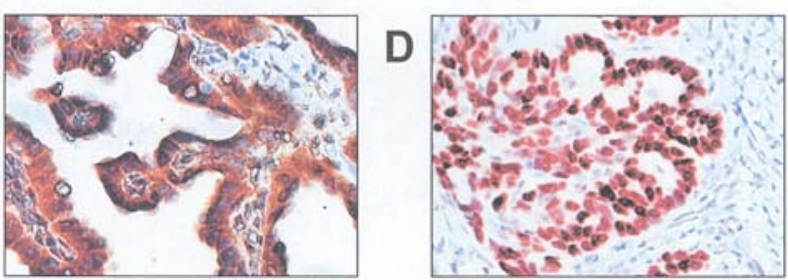

E
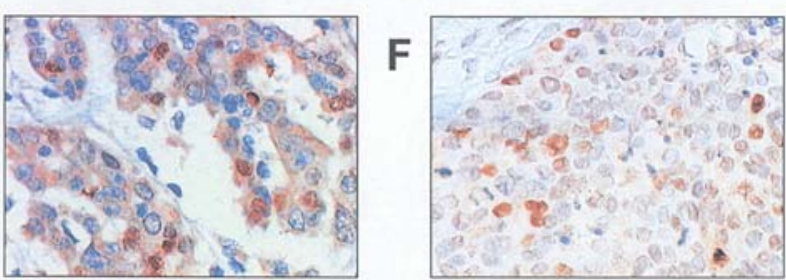

G

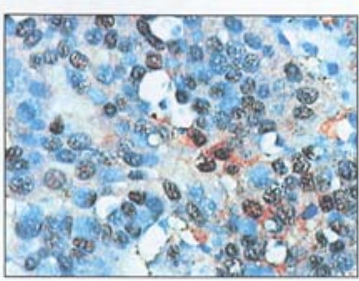

Figure 1. Immunohistochemical localization of analyzed proteins in ovarian carcinoma specimens. (A), hMLH1 expression (x200); (B), hMSH2 expression (x200); (C), Bcl- $\mathrm{x}_{\mathrm{L}}$ expression (x400); (D), p53 expression (x200); (E), p63 expression (x400); $(\mathrm{F}), \mathrm{p} 21$ expression (x400); $(\mathrm{G})$, caspase-3 (active form) expression (x400) (color reaction is localized in cells of apoptotic morphology); each with hematoxylin counterstaining.

was evaluated independently by two pathologists. In cases of divergencies, the evaluation was repeated using double-headed microscope.

Statistical analysis. Kaplan-Meier statistics and log-rank tests were performed using SPSS software (release 12.0.1; SPSS Inc., Chicago, IL, USA) to estimate the significance of differences in survival times. The length of progression-free survival was defined as the time from the primary surgical treatment until the time of diagnosis of a recurrent tumor or death. The $\chi^{2}$-test was used to investigate the association between gene expression and other findings. Cox proportional hazard regression model was used for multivariate analysis of survival. All P-values are given for two-sided tests. P-values of $<0.05$ were considered to be statistically significant.

\section{Results}

Ovarian cancer tissues from 43 patients excised at the time point of first-look laparatomy (FLL) and 30 tissue samples from secondary cytoreduction (SCR) procedures of the same patients collective were analyzed by immunohistochemistry (Fig. 1). The clinical characteristics of examined patients are 
A

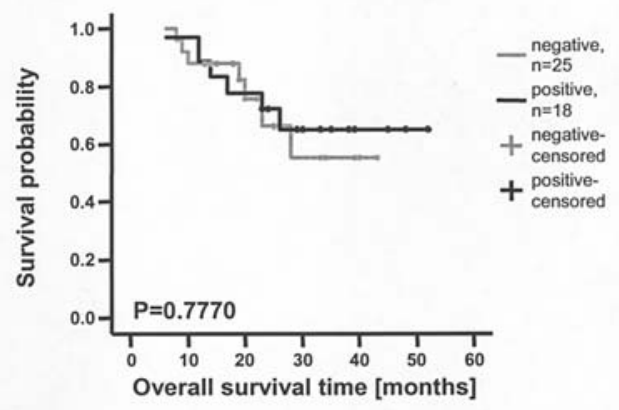

B

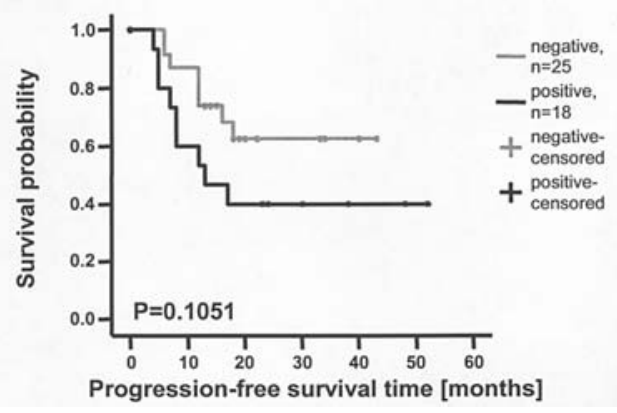

C

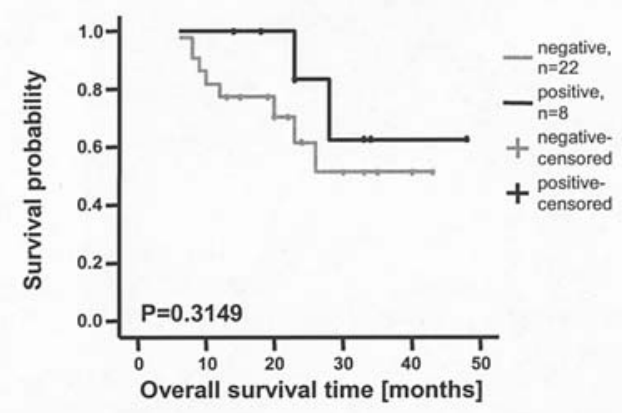

D

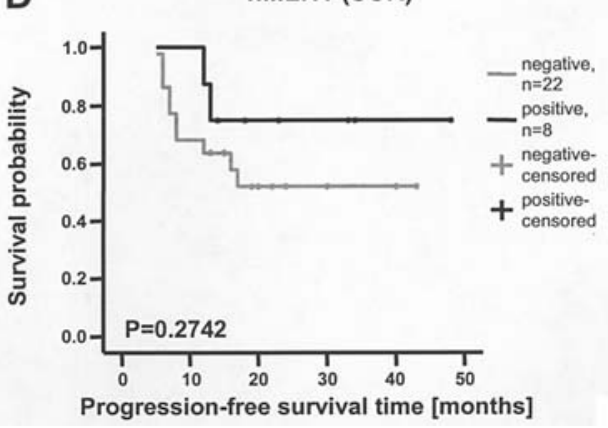

Figure 2. Kaplan-Meier curves for survival and expression of hMLH1 in studied group of 43 ovarian cancer patients. No significant differences in overall survival (A) and progression-free survival (B) at FLL between hMLH1 positive and negative patients; no significant differences in overall survival (C) and progression-free survival (D) at SCR between hMLH1 positive and negative patients.

listed in Table I. Due to the homogeneous set of patients referring to FIGO stage, histology, and applied chemotherapy, we abstained from correlating these parameters with expression differences of the assayed proteins.
Mismatch repair proteins $h M L H 1$ and $h M S H 2$. The immunostaining for the mismatch repair proteins hMLH1 and hMSH2 was evaluated by an immunoreactive score (IRS) from 0 to 12 of the nuclear staining (Table II). hMLH1 protein expression
A

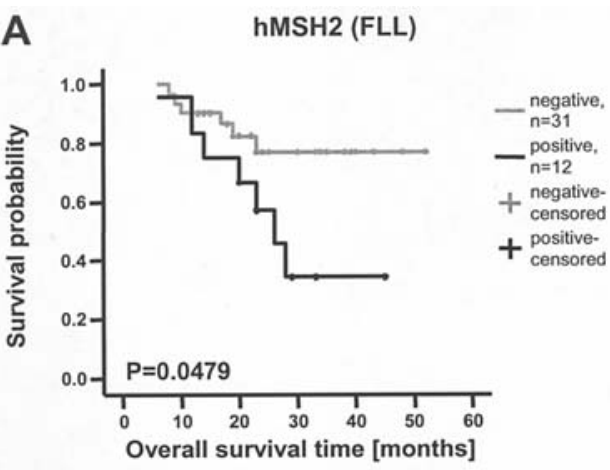

B

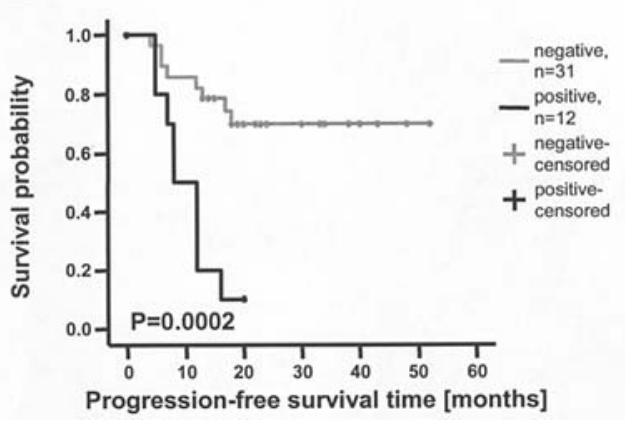

C

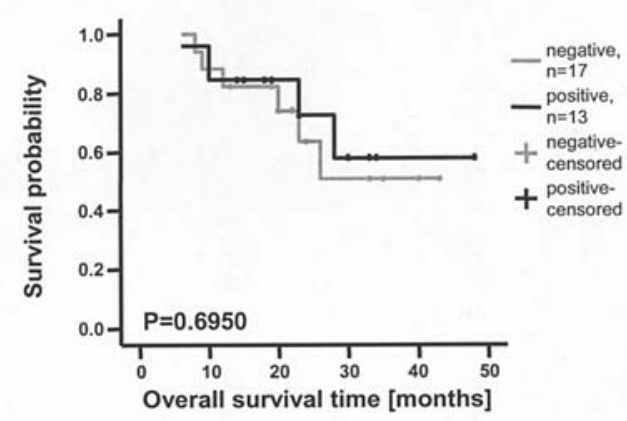

D

hMSH2 (SCR)

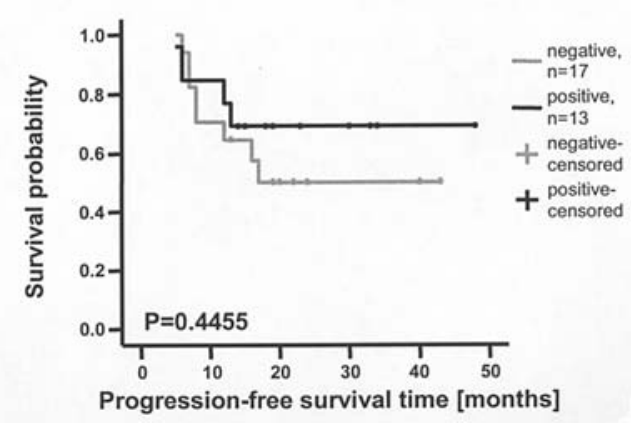

Figure 3. Kaplan-Meier curves for survival and expression of hMSH2 in studied group of 43 ovarian cancer patients. Patients with tumors negative for hMSH2 at FLL have a significant increased overall survival (A) and progression-free survival time (B) as compared to positive cases; no significant differences in overall survival (C) and progression-free survival (D) at SCR between hMSH2 positive and negative patients. 
A

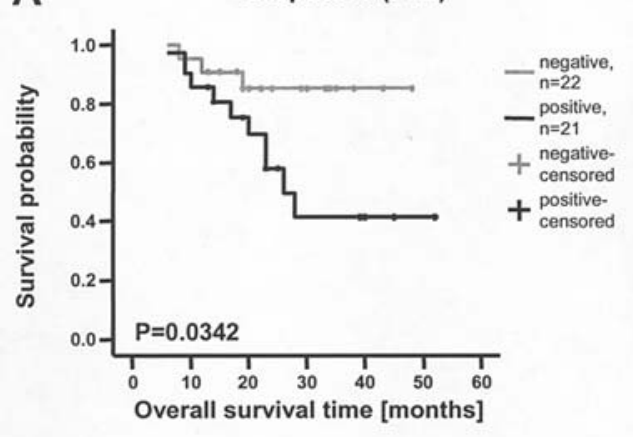

B

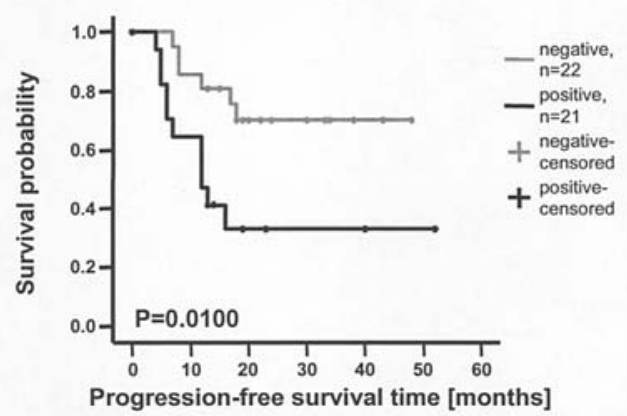

C

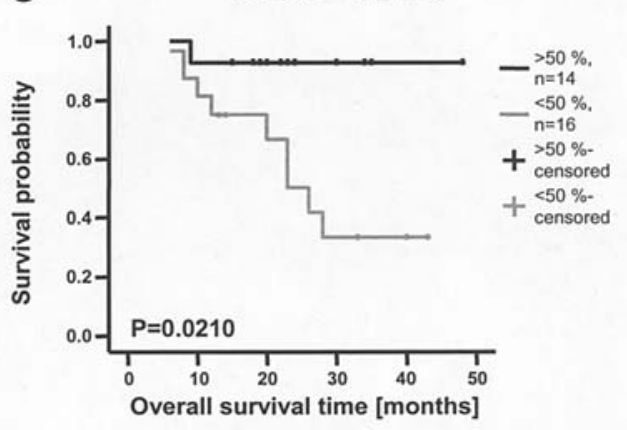

D

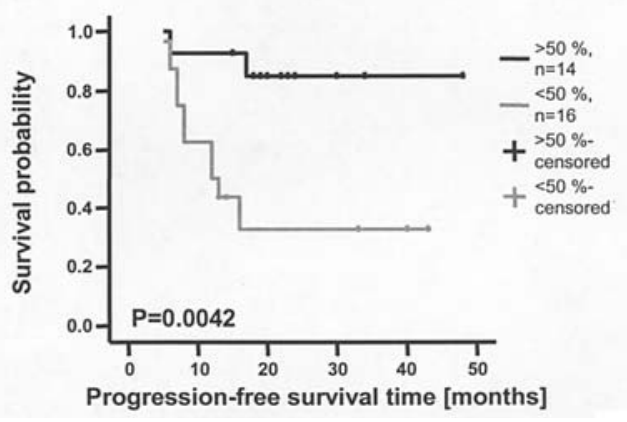

Figure 4. Kaplan-Meier curves for survival and staining of biologically active caspase-3 in studied group of 43 ovarian cancer patients. Positive expression of active caspase-3 before chemotherapy (FLL) significantly shortened overall survival (A) and progression-free survival (B); significant longer overall survival (C) and progression-free survival (D) was observed, when active caspase-3 was expressed in $>50 \%$ of tumor cells after applying chemotherapy (SCR).

was positive in $42 \%$ of FLL and in $27 \%$ of SCR tissues. For hMSH2 protein, $28 \%$ of FLL and $43 \%$ of SCR samples showed a positive staining. There was no significant difference in the mean expression of both proteins in FLL and SCR tissues. Because more than half of the tissue samples showed a negative staining for the examined proteins, the patient collective was divided into two groups (negative or positive) for survival analysis. Examining hMLH1 protein expression, there was no difference either in the overall or in the progression-free survival time (Fig. 2). There was no difference either in the hMLH1 expression between patients who were alive or not. However, patients with negative hMSH2 displayed an advantage in both overall and progression-free survival, when assessed by tissues obtained in FLL (Fig 3A and B; Table III). Additionally, $81 \%$ of patients without hMSH2 staining were alive, in contrast to $42 \%$ of surviving patients who were positive for hMSH2 $\left(\chi^{2}\right.$-test, $\left.\mathrm{P}=0.013\right)$. SCR material was not predictive in this issue (Fig. $3 \mathrm{C}$ and D).

Caspase-3. Caspase-3 expression was evaluated by the percentage of tumor cells showing a positive staining representing the active form of this protein. FLL tissue samples (49\%) were positive for caspase-3, and 14 of these 21 patients expressed caspase- 3 in only up to $5 \%$ of the tumor cells. There was a clear survival advantage in terms of overall and progression-free survival for patients with negative caspase-3 expression before chemotherapy (FLL tissues; Fig. 4A and B). Examining SCR tissue samples, $47 \%$ of patients expressed caspase- 3 in $>50 \%$ of tumor cells and only 3 patients $(10 \%)$ showed no expression of this protein. Patients with expression of caspase- 3 in $>50 \%$ of tumor cells following chemotherapy
(SCR tissues; Fig. 4C and D) had a better prognosis for both overall and progression-free survival (Table III). Because of the tremendous difference in caspase- 3 expression levels in tissues before and after chemotherapy (FLL versus SCR) no common cut off point could be used to evaluate the prognostic significance of this protein.

$B c l-x_{L}$. The expression of the cellular oncoprotein $B c l-x_{L}$ was estimated using IRS (Table II). Patients were divided into two groups with no/low (IRS 0-6) and high (IRS 7-12) Bcl- $\mathrm{x}_{\mathrm{L}}$ expression in the excised tumor tissues. In FLL tissues, 26\% of samples showed no expression of $\mathrm{Bcl}-\mathrm{x}_{\mathrm{L}}$, wheras all patients expressed this protein at least with IRS 3 in tissues obtained by SCR. The median of Bcl- $\mathrm{x}_{\mathrm{L}}$ expression was 4 for FLL and 9 for SCR cancer tissues. Using FLL tissues, patients with a higher Bcl- $\mathrm{X}_{\mathrm{L}}$ expression had clearly a shorter time of progression-free survival (Fig. 5B). In terms of overall survival, we observed also an advantage for patients with no/lower expression of $\mathrm{Bcl}_{\mathrm{L}}$ (Fig. 5A), but this difference was not significant $(\mathrm{P}=0.059$; Table III). There was no significance of $\mathrm{Bcl}-\mathrm{x}_{\mathrm{L}}$ expression for the prediction of clinical outcome, when SCR tissues were used (Fig. 5C and D). Additionally, we could not find any correlations between the expression level of the anti-apoptotic Bcl- $\mathrm{x}_{\mathrm{L}}$ and expression of activated caspase-3, either in FLL or in SCR tissues.

Tumor suppressors p53, p63and p21(WAF1/CIP1). Expression analyses evaluated by IRS were performed for p53, p63 and p21. As expected, all three proteins displayed a nuclear staining in ovarian cancer tissues (Fig. 1D-F). Among FLL 
Table III. Univariate overall and recurrence-free survival analysis.

\begin{tabular}{|c|c|c|c|c|c|}
\hline Factor & $\mathrm{n}$ & $\begin{array}{l}\text { Survival } \\
(\%)^{\mathrm{a}}\end{array}$ & $\begin{array}{c}\text { OS }^{\mathrm{b}} \\
\text { P-value }\end{array}$ & $\begin{array}{l}\text { Recurrence-free } \\
(\%)^{\mathrm{a}}\end{array}$ & $\begin{array}{c}\text { PFS }^{b} \\
\text { P-value }\end{array}$ \\
\hline \multicolumn{6}{|l|}{ hMLH1 } \\
\hline FLL & 43 & & 0.7770 & & 0.1051 \\
\hline Negative & 25 & 72 & & 71 & \\
\hline Positive & 18 & 67 & & 50 & \\
\hline SCR & 30 & & 0.3149 & & 0.2742 \\
\hline Negative & 22 & 64 & & 55 & \\
\hline Positive & 8 & 75 & & 75 & \\
\hline \multicolumn{6}{|l|}{ hMSH2 } \\
\hline FLL & 43 & & 0.0479 & & 0.0002 \\
\hline Negative & 31 & 81 & & 74 & \\
\hline Positive & 12 & 42 & & 25 & \\
\hline SCR & 30 & & 0.6950 & & 0.4455 \\
\hline Negative & 17 & 65 & & 53 & \\
\hline Positive & 13 & 69 & & 69 & \\
\hline \multicolumn{6}{|l|}{ Caspase-3 } \\
\hline FLL & 43 & & 0.0342 & & 0.0100 \\
\hline Negative & 22 & 86 & & 73 & \\
\hline Positive & 21 & 52 & & 48 & \\
\hline SCR & 30 & & 0.0210 & & 0.0042 \\
\hline$<50 \%$ & 16 & 44 & & 37 & \\
\hline$>50 \%$ & 14 & 93 & & 86 & \\
\hline \multicolumn{6}{|l|}{ Bcl- $x_{L}$} \\
\hline FLL & 43 & & 0.0590 & & 0.0012 \\
\hline IRS 0-6 & 27 & 81 & & 78 & \\
\hline IRS 7-12 & 16 & 50 & & 31 & \\
\hline SCR & 30 & & 0.3987 & & 0.7608 \\
\hline IRS 0-6 & 9 & 78 & & 56 & \\
\hline IRS 7-12 & 21 & 62 & & 62 & \\
\hline \multicolumn{6}{|l|}{ p53 } \\
\hline FLL & 43 & & 0.0603 & & 0.0321 \\
\hline IRS 0-4 & 23 & 83 & & 74 & \\
\hline IRS 5-12 & 20 & 55 & & 45 & \\
\hline SCR & 30 & & 0.7109 & & 0.7630 \\
\hline IRS 0-4 & 11 & 73 & & 64 & \\
\hline IRS 5-12 & 19 & 63 & & 58 & \\
\hline \multicolumn{6}{|l|}{ p63 } \\
\hline FLL & 43 & & 0.1306 & & 0.4118 \\
\hline Negative & 21 & 81 & & 67 & \\
\hline Positive & 22 & 59 & & 56 & \\
\hline SCR & 30 & & 0.6061 & & 0.1396 \\
\hline Negative & 12 & 50 & & 42 & \\
\hline Positive & 18 & 78 & & 72 & \\
\hline \multicolumn{6}{|l|}{$\mathrm{p} 21^{(\mathrm{WAF} 1 / \mathrm{CIP} 1)}$} \\
\hline FLL & 43 & & 0.0006 & & 0.0002 \\
\hline IRS 0-2 & 23 & 48 & & 35 & \\
\hline IRS 3-12 & 20 & 95 & & 90 & \\
\hline SCR & 30 & & 0.1319 & & 0.0422 \\
\hline IRS 0-2 & 24 & 59 & & 50 & \\
\hline IRS 3-12 & 6 & 100 & & 100 & \\
\hline
\end{tabular}

${ }^{\mathrm{a} A t}$ the end-point of observation time (max. 52 months). ${ }^{\mathrm{b}}$ Kaplan-Meier analysis, log-rank test. IRS, immunoreactive score; FLL, first-look laparatomy; SCR, secondary cytoreduction; OS, overall survival; PFS, progression-free survival. 
A

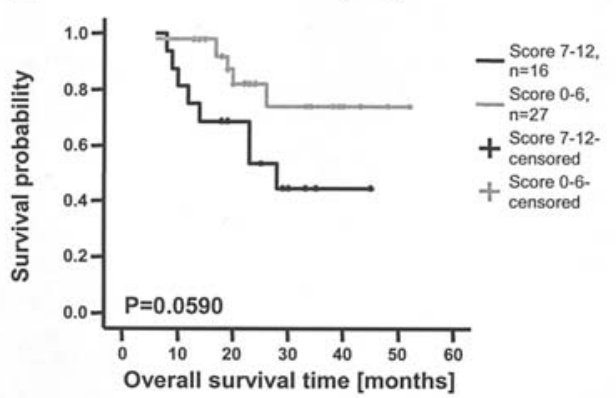

B

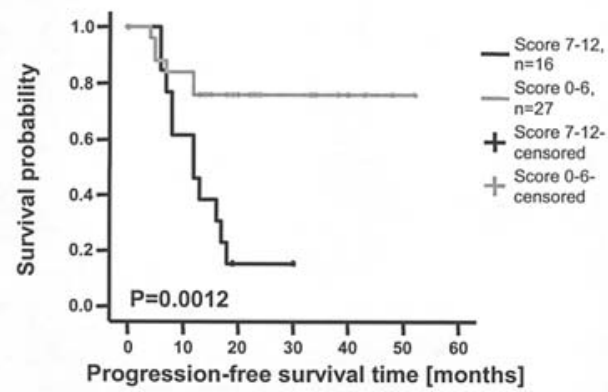

C

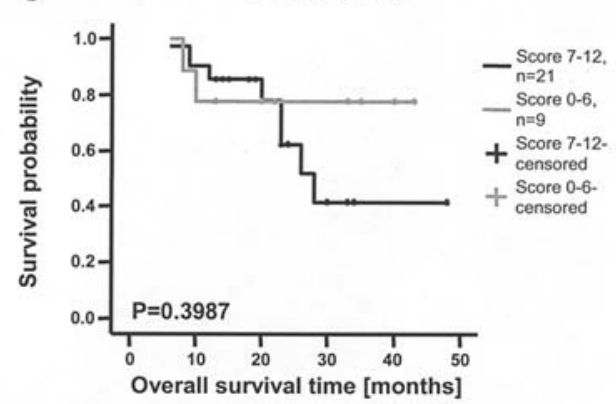

D

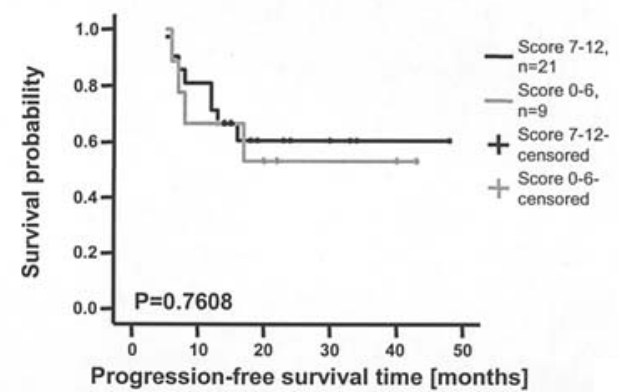

Figure 5. Kaplan-Meier curves for survival and expression of $\mathrm{Bcl}-\mathrm{x}_{\mathrm{L}}$ in studied group of 43 ovarian cancer patients. No significant differences in overall survival (A), but significantly prolonged progression-free survival (B) for patients with low (score 0-6) Bcl- $\mathrm{x}_{\mathrm{L}}$-specific staining at FLL compared to higher Bcl- $\mathrm{x}_{\mathrm{L}}$ expression (score 7-12); no significant differences in overall survival (C) and progression-free survival (D) between patients with low (score 0-6) and high (score 7-12) Bcl- $\mathrm{x}_{\mathrm{L}}$-specific staining at SCR.

tissues, each 4 samples (9\%) were negative for p53 and p21, respectively. The median expression was 4 for p53 and 2 for p21. Regarding tissues from SCR procedures, only one of the samples was negative for p53, and 11 tumors (37\%) showed no staining for $\mathrm{p} 21$ protein. In these tissues, the median protein expression was 6 for $\mathrm{p} 53$ and 1 for $\mathrm{p} 21$. FLL tissues [21/43 (49\%)] and 12/30 (40\%) SCR tissues showed no p63 protein expression, whereas the highest score measured was 6
A

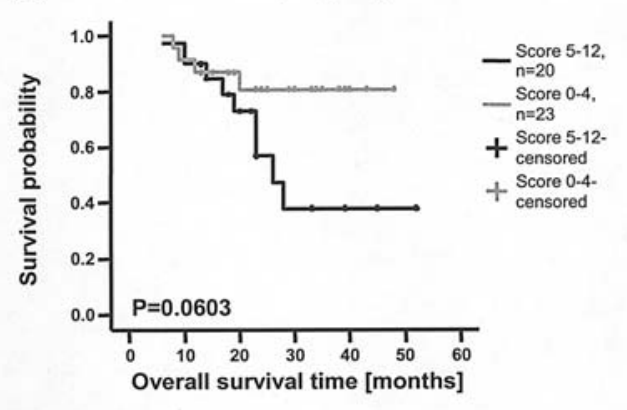

B

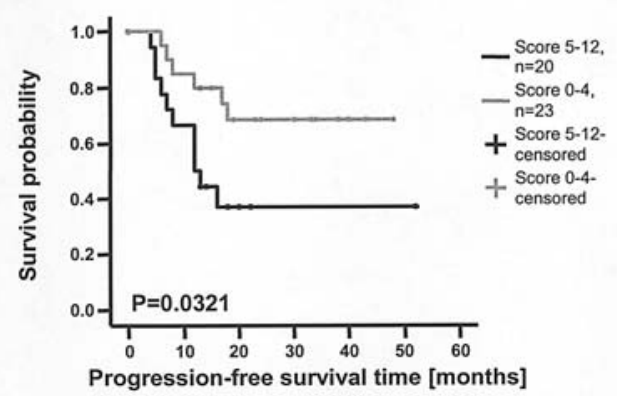

C

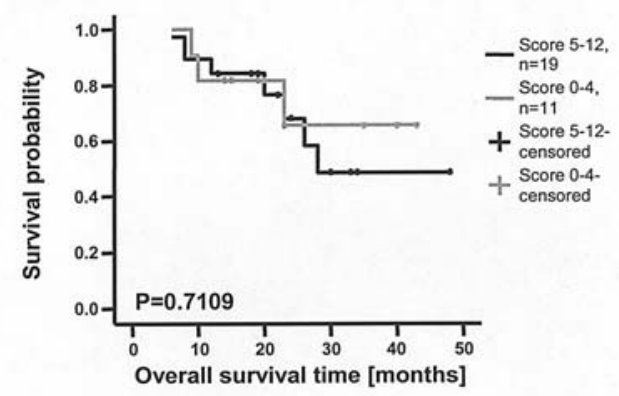

D

p53 (SCR)

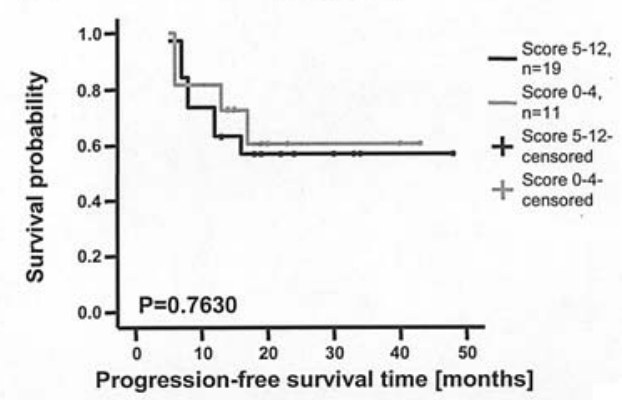

Figure 6. Kaplan-Meier curves for survival and expression of $\mathrm{p} 53$ in studied group of 43 ovarian cancer patients. No significant differences in overall survival (A), but significantly prolonged progression-free survival (B) for patients with low (score 0-4) p53-specific staining at FLL compared to higher p53 expression (score 5-12); no significant differences in overall survival (C) and progression-free survival (D) between patients with low (score 0-4) and high (score 5-12) p53-specific staining at SCR. 
A

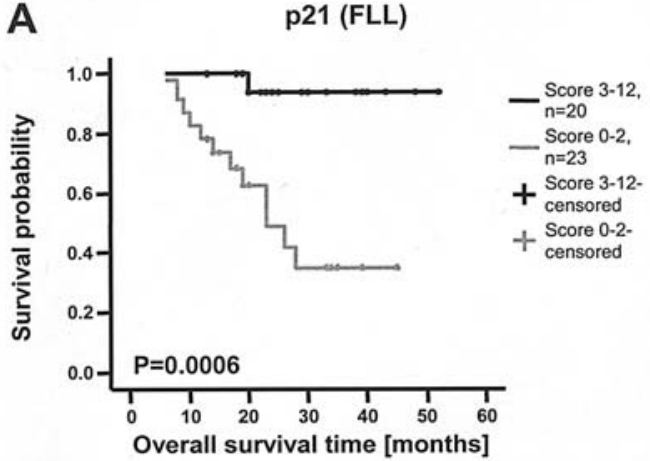

B

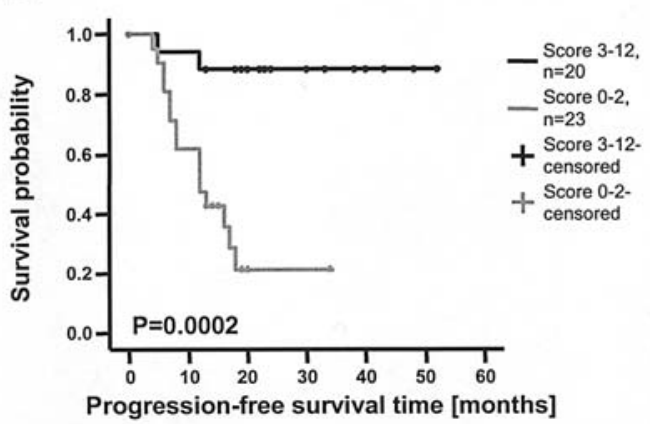

C

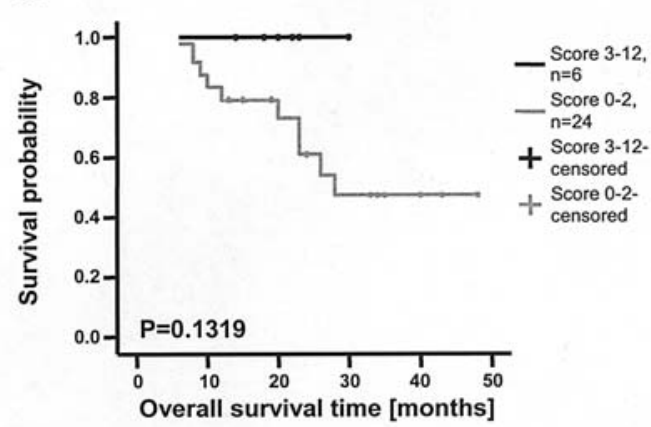

D

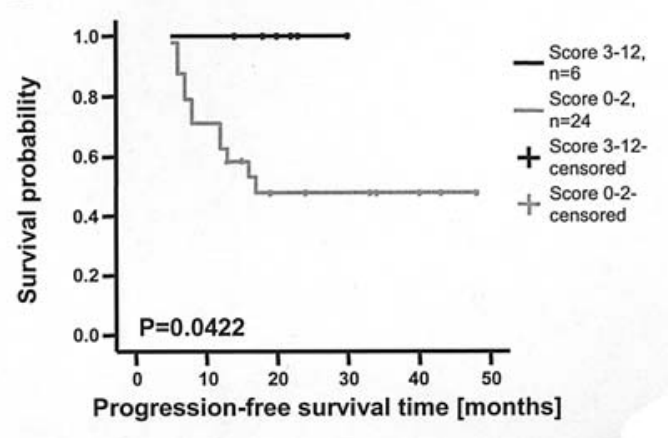

Figure 7. Kaplan-Meier curves for survival and expression of p21 in studied group of 43 ovarian cancer patients. Patients suffering from tumors with high p21-specific staining intensity (score 3-12) at FLL have a high significant increased overall survival (A) and progression-free survival time (B) as compared to patients with tumors showing a low p21-specific staining (score 0-2); no significant differences in overall survival (C) between low (score 0-2) and high (score 3-12) p21-specific staining at SCR, but all 6 patients with high p21 expression were alive until the end of observation time; patients suffering from tumors with high p21-specific staining intensity (score 3-12) at SCR have a significant increased progression-free time (D) as compared to patients with tumors showing a low p21-specific staining (score $0-2$ ).

and 8 in FLL and SCR tissues, respectively. Using tissues from FLL procedures, patients with lower expression of p53 protein (IRS 0-4) presented an advantage in progression-free survival (Fig. 6B). Although a strong tendency was also seen in the context of overall survival for patients with lower p53 expression in Kaplan-Meier diagrams, the significance level was not achieved ( $\mathrm{P}=0.060$; Fig. 6A; Table III). Analysis of p53 expression in SCR tissues was not predictive for clinical outcome (Fig. 6C and D). In both FLL and SCR tissues, evaluation of p21 expression provided conspicuous results. There was a marked advantage in overall and progressionfree survival for patients with higher expression of p21 (Fig 7). Despite the fact that all patients with higher $\mathrm{p} 21$ expression were still alive and progression-free at the end of observation time, the significance level for overall survival analysis was missed due to the small number of cases in this group ( $\mathrm{P}=0.132$; Table III). No correlation was observed for p53 and p21 expression in FLL and SCR tissues. There was no association of p53 expression level in FLL tissues with the p21 expression level in SCR tissues after chemotherapy. No statistically relevant survival advantage could be observed for patients with or without p63 protein expression (Fig. 8). Nevertheless, it should be recognized, that the percentage of surviving patients and patients with recurrence-free survival until the end of observation time was higher in patients with negative p63 staining in FLL tissues and for patients with positive staining in SCR tissues (Table III).
Multivariate analysis. Although our set of patients was relatively small in number, we performed explorative multivariate analyses for all immunohistologically analyzed factors in FLL and SCR tissues (Table IV). Because age of patients and grading were not statistically significant for survival in univariate or in multivariate analysis (data not shown), we abstained from including these factors in our model. Furthermore, nearly all cancer specimens diagnosed were in stage FIGO III, thus, staging could be not included in the analysis. Expression of caspase-3 and p21 were shown to be independent prognosic factors for overall and progressionfree survival before applying chemotherapy. Additionally, caspase-3 expression was also predictive for overall and progression-free survival after administering chemotherapy. Interestingly, also hMLH1 and hMSH2 expression were independent prognostic markers for overall survival in SCR tissues, although hMLH1 was not significant in univariate analysis.

\section{Discussion}

Despite the advances in therapy of ovarian cancer, this cancer entity is still a disease with poor prognosis. To obtain further information on the behavior of cancer cells under cytostatic drug treatment, we analyzed the protein expression of a set of genes in ovarian cancer patients by immunohistochemistry before and after platinum-based chemotherapy. The 
A

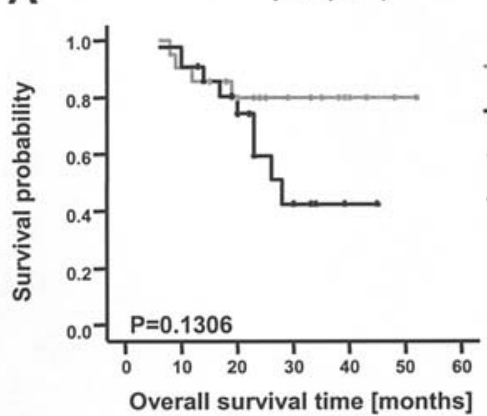

B
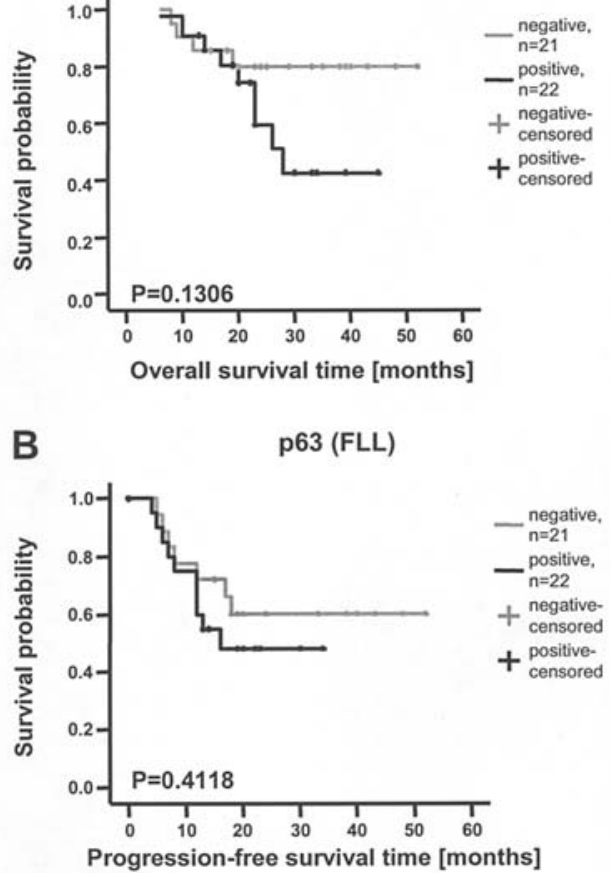

C

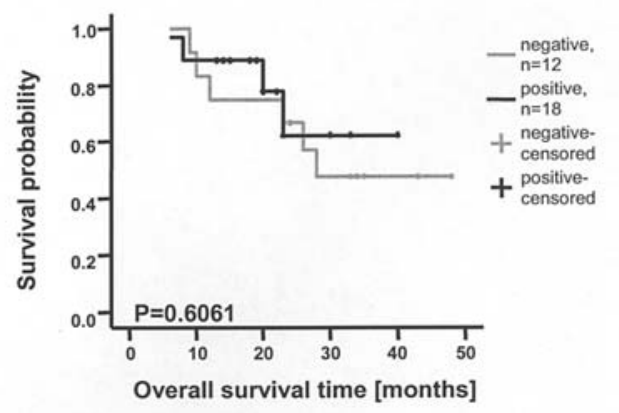

D

p63 (SCR)

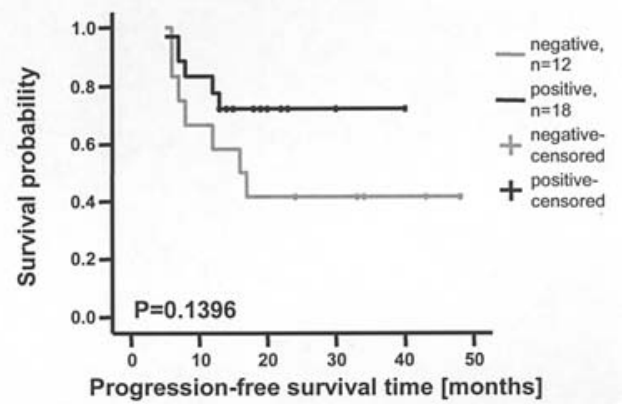

Figure 8. Kaplan-Meier curves for survival and expression of p63 in studied group of 43 ovarian cancer patients. No significant differences in overall survival (A) and progression-free survival (B) at FLL between p63 positive and negative patients; no significant differences in overall survival (C) and progressionfree survival (D) at SCR between p63 positive and negative patients.

obtained data were correlated with clinical outcome with the intention of identifying prognostic markers, and possibly finding new objectives for improving ovarian cancer therapy.
Loss of DNA MMR is known to be an important mechanism for the development of platinum resistance in human cancer cell lines (46-48). The first studies examining the most important MMR proteins, hMLH1 and hMSH2,

Table IV. Multivariate overall and progression-free survival analysis.

\begin{tabular}{|c|c|c|c|c|c|c|}
\hline & \multicolumn{3}{|c|}{ Overall survival } & \multicolumn{3}{|c|}{ Progression-free survival } \\
\hline & HR & $95 \% \mathrm{CI}$ & P-value & HR & $95 \% \mathrm{CI}$ & P-value \\
\hline \multicolumn{7}{|l|}{ FLL } \\
\hline hMLH1 & 0.682 & $0.213-2.187$ & 0.520 & 2.082 & $0.752-5.764$ & 0.158 \\
\hline hMSH2 & 2.285 & $0.483-10.808$ & 0.297 & 3.507 & $0.911-13.495$ & 0.068 \\
\hline Caspase-3 & 9.402 & $1.383-63.919$ & 0.022 & 7.946 & $1.294-48.802$ & 0.025 \\
\hline $\mathrm{Bcl}-\mathrm{x}_{\mathrm{L}}$ & 0.709 & $0.179-2.810$ & 0.624 & 0.806 & $0.215-3.018$ & 0.749 \\
\hline p53 & 0.364 & $0.041-3.232$ & 0.365 & 0.765 & $0.153-3.816$ & 0.744 \\
\hline p63 & 0.241 & $0.029-2.002$ & 0.188 & 0.200 & $0.036-1.128$ & 0.068 \\
\hline $\mathrm{p} 21$ & 0.018 & $0.001-0.274$ & 0.004 & 0.048 & $0.005-0.424$ & 0.006 \\
\hline \multicolumn{7}{|l|}{ SCR } \\
\hline hMLH1 & 0.019 & $0.001-0.387$ & 0.010 & 0.098 & $0.009-1.093$ & 0.059 \\
\hline hMSH2 & 12.117 & $1.110-132.318$ & 0.041 & 4.683 & $0.675-32.507$ & 0.118 \\
\hline Caspase-3 & 0.043 & $0.002-0.774$ & 0.033 & 0.117 & $0.017-0.808$ & 0.030 \\
\hline $\mathrm{Bcl}-\mathrm{x}_{\mathrm{L}}$ & 12.907 & $0.909-183.288$ & 0.059 & 1.536 & $0.252-9.347$ & 0.641 \\
\hline p53 & 0.439 & $0.049-3.924$ & 0.462 & 0.974 & $0.180-5.281$ & 0.976 \\
\hline p63 & 1.056 & $0.245-4.548$ & 0.941 & 0.578 & $0.168-1.990$ & 0.385 \\
\hline $\mathrm{p} 21$ & 0.000 & 0.000-n.v. & 0.978 & 0.000 & $0.000-\mathrm{n} . \mathrm{v}$. & 0.977 \\
\hline
\end{tabular}

HR, hazard ratio; CI, confidence interval of hazard ratio; FLL, first-look laparatomy; SCR, secondary cytoreduction; n.v., no value given by SPSS statistical program. 
resulted in contradictory conclusions (4-7), so that further analyses are needed to clarify the clinical importance of these factors. In this study, we analyzed ovarian cancer patients for their expression of hMLH1 and hMSH2 using immunohistochemistry. In contrast to previous reported results in ovarian cancer patients $(n=54)(6)$, we could not detect any significant difference in the mean expression before and after chemotherapy for either protein. But is has to be considered, that $>50 \%$ of analyzed tissue samples reported here showed no expression of hMLH1 and hMSH2, respectively. Nonetheless, in agreement with Samimi et al (6), we did not find any influence of hMLH1 expression on patient's survival in univariate analysis. Moreover, hMLH1 was shown to be an independent prognostic marker for overall survival using multivariate analysis indicating an influence on clinical outcome of ovarian cancer patients. An increased amount of hMSH2 protein was reported to be an independent prognostic indicator of survival in ovarian carcinoma patients $(n=102)$ by multivariate analysis (5), although there was no significant difference in hMSH2 protein staining between patients that were alive and those who were not. Another study also described significantly lower hMSH2 protein level in ovarian cancer patients not responding to the applied chemotherapy by Western blot analysis of ascites $(n=9)$ and solid tumors $(n=10)$ (4). In the present study, we found that a positive hMSH2 expression before chemotherapy is an unfavorable prognostic factor in overall and progression-free survival. It has been annotated previously, that the MMR system may contribute to cisplatin toxicity by alternative mechanisms, as hMSH2 may bind to cisplatin-DNA-adducts, shielding them from repair and allowing them to persist without triggering apoptosis as a consequence (49). In this context, tumor cells with higher hMSH2 expression level without apoptosis or repair inducing stress (here: before chemotherapy), could use this way to survive after onset of chemotherapeutic treatment resulting in a worse clinical outcome.

Activated caspase- 3 is regarded to be the key protein in triggering apoptosis (30), and was reported to cleave $\mathrm{p} 21^{(\mathrm{WAF} 1 / \mathrm{CIP} 1)}$. The cleaved $\mathrm{p} 21$ fragment is no longer able to arrest the cells in G1 phase, so that the cells undergo apoptosis after intense DNA damage (50). Hence, we supposed that the expression of activated caspase- 3 could be a good marker for the assessment of chemotherapeutic effectiveness. As expected, there was a clear survival advantage for patients showing a higher percentage of apoptotic cancer cells after applying chemotherapy, in expressing higher amounts of activated caspase- 3 . We showed that a positive staining for active caspase-3 in cancer tissues before chemotherapy is a negative prognostic factor for ovarian cancer patients. Overexpression of caspase-3 without an apoptotic stimulus could refer to abnormal regulative pathways or may be due to mutations in caspase- 3 resulting in decrease or loss of function. Prior analyses of human cancer cell lines showed that overexpression of anti-apoptotic genes can affect the activity of caspase- $3(33,51)$. However, we did not observe a correlation between Bcl- $\mathrm{x}_{\mathrm{L}}$ and caspase- 3 expression.

The anti-apoptotic protein $\mathrm{Bcl}-\mathrm{x}_{\mathrm{L}}$ was reported to show higher expression level in ovarian carcinoma tissues compared with normal ovaries $(41,52,53)$ and has frequently been examined in the context of chemoresistance $(38,54)$.
Nevertheless, very little is known about the prognostic relevance of $\mathrm{Bcl}-\mathrm{x}_{\mathrm{L}}$ in ovarian cancer patients. Using the IRS (45), we observed a longer progression-free survival time in patients with no or lower $\mathrm{Bcl}-\mathrm{x}_{\mathrm{L}}$ protein expression in univariate analysis, which is consistent with a previously described study on an ovarian carcinoma collective with a smaller number of patients $(n=28)$ using a different scoring system (54). As in that study, we could not find a statistically significant difference in overall survival, although the survival time in patients with no or lower $\mathrm{Bcl}-\mathrm{x}_{\mathrm{L}}$ was longer. We found also concordance with the fact, that $\mathrm{Bcl}-\mathrm{x}_{\mathrm{L}}$ was expressed at higher level in patients after platinum-based chemotherapy. However, Bcl- $\mathrm{X}_{\mathrm{L}}$ expression was not an independent prognostic marker in multivariate analysis. Further analyses with a more numerous set of ovarian cancer patients should be performed to clarify these data.

Mutations of p53 and/or p53 protein overexpression have been detected in $20-84 \%$ of ovarian cancers, and p53 alteration rate was reported to be higher in advanced than in early stages of the disease $(24,55)$. Expression of p53 has been studied extensively by immunohistochemistry, using archival formalin-fixed, paraffin-embedded tissues. These tissues would show reduced immunoreactivity of many proteins due to the fixation process (55). In our study with paraffinembedded tissues, we observed a positive staining in 39/43 $(91 \%)$ of cases, which is above the average percentage, but comparable to the previously determined $74 \%$ positive p53 staining with the same antibody in snap-frozen ovarian cancer tissues (55). It was reported previously, that paclitaxelinduced apoptosis is not dependent on p53 status, wheras cisplatin-induced apoptosis requires wild-type p53 (1012,56). Most of the patients in our study were administered a platinum- and paclitaxel-based chemotherapy, so that in theory the combination of both should have been able to induce apoptosis in all cancer cells independent of the existing p53 status. Nevertheless, we found in univariate analysis of cancer tissues before chemotherapy, that a higher expression of p53, which is probably mutated (9), represents an unfavorable prognosis factor in ovarian cancer patients.

Unlike p53, p63 is not a tumor suppressor gene and has been reported to be frequently amplified and/or overexpressed in various cancer entities, e.g., lung cancer and squamous cell carcinomas of head and neck (57). Down-regulation of p63 was observed in bladder and breast cancers associated with loss of differention and enhanced invasiveness, respectively $(58,59)$. Because the p63 gene has two promoters and occurs in various isoforms with different expression patterns and functions (57), it is very difficult to clarify the importance of p63 for clinical outcome and chemoresistance. In this study we used an anti-p63 antibody which detects four of the six isotypes of p63. We could not observe any significant difference in survival time for ovarian cancer patients expressing p63 or not. Similar findings were previously published by others (60) using a different antibody detecting all known isoforms. But, an impact of p63 expression cannot be excluded, because the variety of isoforms which may possess opposite functions, thus more detailed analyses should be implemented.

$\mathrm{p} 21^{\text {(WAF1/CIP1) }}$ is a potent inhibitor of cyclin-dependent kinases, which are necessary for cell cycle progression, and 
functions as a central checkpoint in cell cycle control. Although p21 can be induced by p53 during DNA damage induced cell cycle arrest and apoptosis, there is sufficient evidence that p21 can be up-regulated independently of p53 (61). In this study, we could not see any correlation between p21 and p53 expression, which is consistent with previous trials (62). Therefore, apart from the p53-dependent induction of p21 further independent mechanisms of apoptosis induction seem to be involved. We also found p21 protein expression to be a meaningful prognostic marker in ovarian carcinoma patients especially when tissues before chemotherapy were exerted for analysis. These results are concordant with previous studies on ovarian carcinoma patients, which analyzed lower $(\leq 10 \%$ positive) and higher ( $>10 \%$ positive) expressions of p21 in the context of overall and progression-free survival $(22,63)$, whereas studies comparing patients with negative and positive staining for $\mathrm{p} 21$ did not show any influence on patient's survival $(19,62)$.

In conclusion, this study shows the importance of analyzed MMR and apoptosis-related proteins to clinical outcome. Exept p63, all examined proteins were predictive to some extent in univariate and/or multivariate analysis. In particular, protein expression of active caspase- 3 and p21 can be used as prognostic markers for disease progression and effectiveness of applied chemotherapy.

\section{Acknowledgements}

The study was supported by the 'Berliner Krebsgesellschaft e.V.', Germany.

\section{References}

1. Jemal A, Tiwari RC, Murray T, Ghafoor A, Samuels A, Ward E, Feuer EJ, Thun MJ and American Cancer Society: Cancer statistics, 2004. CA Cancer J Clin 54: 8-29, 2004.

2. McGuire WP, Hoskins WJ, Brady MF, Kucera PR, Partridge EE, Look KY, Clarke-Pearson DL and Davidson M: Cyclophosphamide and cisplatin compared with paclitaxel and cisplatin in patients with stage III and stage IV ovarian cancer. N Engl J Med 334: 1-6, 1996.

3. Lage $\mathrm{H}$ and Dietel M: Involvement of the DNA mismatch repair system in antineoplastic drug resistance. J Cancer Res Clin Oncol 125: 156-165, 1999.

4. Ercoli A, Ferrandina G, Raspaglio G, Marone M, Maggiano N, Del Mastro P, Benedetti Panici P, Mancuso S and Scambia G: hMSH2 and GTBP expression in advanced stage epithelial ovarian cancer. Br J Cancer 80: 1665-1671, 1999.

5. Geisler JP, Geisler HE, Miller GA, Wiemann MC, Zhou Z and Crabtree W: Immunohistochemical staining of the mismatch repair gene, hMSH2, and survival in patients with ovarian carcinoma. Eur J Gynaecol Oncol 21: 237-240, 2000.

6. Samimi G, Fink D, Varki NM, Husain A, Hoskins WJ, Alberts DS and Howell SB: Analysis of MLH1 and MSH2 expression in ovarian cancer before and after platinum drug-based chemotherapy. Clin Cancer Res 6: 1415-1421, 2000.

7. Scartozzi M, De Nictolis M, Galizia E, Carassai P, Bianchi F, Berardi R, Gesuita R, Piga A, Cellerino R and Porfiri E: Loss of hMLH1 expression correlates with improved survival in stage III-IV ovarian cancer patients. Eur J Cancer 39: 1144-1149, 2003.

8. Greenblatt $\mathrm{M}$ and Harris $\mathrm{C}$ : Mutations in the p53 tumor suppressor gene: clues to cancer etiology and molecular pathogenesis. Cancer Res 54: 4855-4878, 1994.

9. Iggo R, Gatter K, Bartek J, Lane D and Harris AL: Increased expression of mutant forms of p53 oncogene in primary lung cancer. Lancet 335: 675-679, 1990.

10. Lowe SW, Ruley HE, Jacks T and Housman E: p53-dependent apoptosis modulates the cytotoxicity of anticancer agents. Cell 74: 957-967, 1993.
11. Vasey PA, Jones NA, Jenkins S, Dive C and Brown R: Cisplatin, camptothecin and Taxol sensitivities of cells with p53-associated multidrug resistance. Mol Pharmacol 50: 1536-1540, 1996.

12. Vikhanskaya F, Clerico L, Valenti M, Stanzione MS, Broggini M, Parodi S and Russo P: Mechanism of resistance to cisplatin in a human ovarian-carcinoma cell line selected for resistance to doxorubicin: possible role of p53. Int J Cancer 72: 155-159, 1997.

13. Branch P, Masson M, Aquilina G, Bignami M and Karran P: Spontaneous development of drug resistance: mismatch repair and p53 defects in resistance to cisplatin in human tumor cells. Oncogene 19: 3138-3145, 2000.

14. Harper JW, Adami GR, Wei N, Keyomarsi K and Elledge SJ: The p21 Cdk-interacting protein Cip is a potent inhibitor of G1 cyclin-dependent kinases. Cell 75: 805-816, 1993.

15. El-Deiry WS, Harper JW, O'Connor PM, Velculescu VE, Canman CE, Jackman J, Pietenpol JA, Burrell M, Hill DE, Wang Y, Wiman KG, Mercer WE, Kastan MB, Kohn KW, Elledge SJ, Kinzler KW and Vogelstein B: WAF1/CIP1 is induced in p53-mediated G1 arrest and apoptosis. Cancer Res 54: 1169-1174, 1994.

16. Jiang H, Lin J, Su ZZ, Collart FR, Huberman E and Fisher PB: Induction of differentiation in human promyelocytic HL-60 leukemia cells activates $\mathrm{p} 21$, WAF1/CIP1, expression in the absence of p53. Oncogene 9: 3397-3406, 1994.

17. Elbendary A, Berchuck A, Davis P, Havrilesky L, Bast RC, Iglehart D and Marks JR: Transforming growth factor $B 1$ can induce CIP1/WAF1 expression independent of the p53 pathway in ovarian cancer cells. Cell Growth Differ 5: 1301-1307, 1994.

18. Michieli P, Chedid M, Lin D, Pierce JH, Mercer WE and Givol D: Induction of WAF1/CIP1 by a p53-independent pathway. Cancer Res 54: 3391-3395, 1994.

19. Schuyer M, van der Burg MEL, Henzen-Logmans SC, Fieret JH, Klijn JGM, Look MP, Foekens JA, Stoter G and Berns EMJJ: Reduced expression of BAX is associated with poor prognosis in patients with epithelial ovarian cancer: a multifactorial analysis of TP53, p21, BAX and BCL-2. Br J Cancer 85: 1359-1367, 2001.

20. Plisiecka-Halasa J, Karpinska G, Szymanska T, Ziolkowska I, Madry R, Timorek A, Debniak J, Ulanska M, Jedryka M, Chudecka-Glaz A, Klimek M, Rembiszewska A, Kraszewska E, Dybowski B, Markowska J, Emerich J, Pluzanska A, Goluda M, Rzepka-Gorska I, Urbanski K, Zielinski J, Stelmachow J, Chrabowska M and Kupryjanczyk J: P21WAF1, P27KIP1, TP53 and C-MYC analysis in 204 ovarian carcinomas treated with platinum-based regimens. Ann Oncol 14: 1078-1985, 2003.

21. Tachibana M, Watanabe J, Matsushima Y, Nishida K, Kobayashi Y, Fujimura M and Shiromizu K: Independence of the prognostic value of tumor suppressor protein expression in ovarian adenocarcinomas: a multivariate analysis of expression of $\mathrm{p} 53$, retinoblastoma and related proteins. Int J Gynecol Cancer 13: 598-606, 2003.

22. Bali A, O'Brien PM, Edwards LS, Sutherland RL, Hacker NF and Henshall SM: Cyclin D1, p53 and p21Waf1/Cip1 expression is predictive of poor clinical outcome in serous epithelial ovarian cancer. Clin Cancer Res 10: 5168-5177, 2004.

23. Eltabbakh GH, Mount SL, Beatty B, Simmons-Arnold L, Cooper K and Morgan A: Factors associated with cytoreductibility among women with ovarian carcinoma. Gynecol Oncol 95: 377-383, 2004.

24. Gadducci A, Cosio S, Muraca S and Genazzani R: Molecular mechanisms of apoptosis and chemosensitivity to platinum and paclitaxel in ovarian cancer: biological data and clinical implications. Eur J Gynaecol Oncol 23: 390-396, 2002.

25. Mills AA, Zheng B, Wang XJ, Vogel H, Roop DR and Bradley A: p63 is a p53 homologue required for limp and epidermal morphogenesis. Nature 398: 708-713, 1999.

26. Yang A, Schweitzer R, Sun D, Kaghad M, Walker N, Bronson RT, Tabin C, Sharpe A, Caput D, Crum C and McKeon F: p63 is essential for regenerative proliferation in limb, craniofacial and epithelial development. Nature 398: 714-718, 1999.

27. De Laurenzi V and Melino G: Evolution of functions within the p53/p63/p73 family. Ann NY Acad Sci 926: 90-100, 2000.

28. Zeimet AG and Marth C: Why did p53 gene therapy fail in ovarian cancer? Lancet Oncol 4: 415-422, 2003.

29. Kaufmann SH and Vaux DL: Alterations in the apoptotic machinery and their potential role in anticancer drug resistance. Oncogene 22: 7414-7430, 2003. 
30. Enari M, Talanian RV, Wong WW and Nagata S: Sequential activation of ICE-like and CPP32-like proteases during Fasmediated apoptosis. Nature 380: 723-726, 1996.

31. Yang XH, Sladek TL, Liu X, Butler BR, Froelich CJ and Thor AD: Reconstitution of caspase 3 sensitizes MCF-7 breast cancer cells to doxorubicin- and etoposide-induced apoptosis. Cancer Res 61: 348-354, 2001.

32. Devarajan E, Sahin AA, Chen JS, Krishnamurthy RR, Aggarwal N, Brun AM, Sapino A, Zhang F, Sharma D, Yang XH, Tora AD and Mehta K: Down-regulation of caspase 3 in breast cancer: a possible mechanism for chemoresistance. Oncogene 21: 8843-8851, 2002.

33. Yang X, Zheng F, Xing H, Gao Q, Wei W, Lu Y, Wang S, Zhou J, $\mathrm{Hu} \mathrm{W}$ and Ma D: Resistance to chemotherapy-induced apoptosis via decreased caspase-3 activity and overexpression of antiapoptotic proteins in ovarian cancer. J Cancer Res Clin Oncol 130: 423-428, 2004.

34. O'Neill AJ, Boran SA, O'Keane C, Coffey RN, Hegarty NJ, Hegarty P, Gaffney EF, Fitzpatrick JM and Watson RW: Caspase 3 expression in benign prostatic hyperplasia and prostate carcinoma. Prostate 47: 183-188, 2001.

35. Flick MB, O'Malley D, Rutherford T, Rodov S, Kamsteeg M, Hao XY, Schwartz P, Kacinski BM and Mor G: Apoptosisbased evaluation of chemosensitivity in ovarian cancer patients. J Soc Gynecol Investig 11: 252-259, 2004.

36. Saito T, Takehara M, Tanaka R, Lee R, Horie M, Wataba K, Ito E and Kudo R: Correlation between responsiveness of neoadjuvant chemotherapy and apoptosis-associated proteins for cervical adenocarcinoma. Gynecol Oncol 92: 284-292, 2004.

37. Antonsson B and Martinou JC: The Bcl-2 protein family. Exp Cell Res 256: 50-57, 2000

38. Liu JR, Fletcher B, Page C, Hu C, Nunez G and Baker V: Bcl-xL is expressed in ovarian carcinoma and modulates chemotherapyinduced apoptosis. Gynecol Oncol 70: 398-403, 1998.

39. Olopade OI, Adeyanju MO, Safa AR, Hagos F, Mick R, Thompson CB and Recant WM: Overexpression of BCL-X protein in primary breast cancer is associated with high tumor grade and nodal metastases. Cancer J Sci Am 3: 230-237, 1997.

40. Beale PJ, Rogers P, Boxall F, Sharp SY and Kelland LR: BCL-2 familiy protein expression and platinum drug resistance in ovarian carcinoma. Br J Cancer 82: 436-440, 2000.

41. Shigemasa K, Katoh O, Shiroyama Y, Mihara S, Mukai K, Nagai $\mathrm{N}$ and Ohama K: Increased MCL-1 expression is associated with poor prognosis in ovarian carcinomas. Jpn J Cancer Res 93: 542-550, 2002.

42. Therasse P, Arbuck SG, Eisenhauer EA, Wanders J, Kaplan RS, Rubinstein L, Verweij J, van Glabbeke M, van Oosterom AT, Christian MC and Gwyther SG: New guidelines to evaluate the response to treatment in solid tumors. J Natl Cancer Inst 92: 205-216, 2000

43. Sobin LH and Wittekind C (eds): TNM Classification of Malignant Tumors. UICC Wiley-Liss, New York, 2002.

44. Shimizu Y, Kamoi S, Amada S, Akiyama F and Silverberg SG: Toward the development of a universal grading system for ovarian epithelial carcinoma. Cancer 82: 893-901, 1998.

45. Remmele W and Stegner HE: Recommendation for uniform definition of an immunoreactive score (IRS) for immunohistochemical estrogen receptor detection (ER-ICA) in breast cancer tissue (article in German). Pathologe 8: 138-140, 1987.

46. Aebi S, Kurdi-Haidar B, Gordon R, Cenni B, Zheng H, Fink D, Christen RD, Boland CR, Koi M, Fishel R and Howell SB: Loss of DNA mismatch repair in acquired resistance to cisplatin. Cancer Res 56: 3087-3090, 1996.

47. Drummond JT, Anthoney A, Brown R and Modrich P: Cisplatin and adriamycin resistance are associated with MutLalpha and mismatch repair deficiency in an ovarian tumor cell line. J Biol Chem 271: 19645-19648, 1996.

48. Brown R, Hirst GL, Gallagher WM, McIlwrath AJ, Margison GP, van der Zee AGJ and Anthoney DA: hMLH1 expression and cellular response of ovarian tumour cells to treatment with cytotoxic anticancer agents. Oncogene 15: 45-52, 1997.
49. Mello JA, Acharya S, Fishel R and Essigmann JM: The mismatchrepair protein hMSH2 binds selectively to DNA adducts of the anticancer drug cisplatin. Chem Biol 3: 579-589, 1996.

50. Zhang Y, Fujita N and Tsuruo T: Caspase-mediated clevage of p21Waf1/Cip1 converts cancer cells from growth arrest to undergoing apoptosis. Oncogene 18: 1131-1138, 1999.

51. Ding Z, Yang X, Pater A and Tang SC: Resistance to apoptosis is correlated with the reduced caspase- 3 activation and enhanced expression of anti-apoptotic proteins in human cervival multidrugresistant cells. Biochem Biophys Res Commun 270: 415-420, 2000 .

52. Marone M, Scambia G, Mozzetti S, Ferrandina G, Iacovella S, De Pascqua A, Benedetti-Panici P and Mancuso S: Bcl-2, bax, bcl-XL and bcl-XS expression in normal and neoplastic ovarian tissues. Clin Cancer Res 4: 517-524, 1998.

53. Baekelandt M, Holm R, Nesland JM, Trope CG and Kristensen GB: Expression of apoptosis-related proteins in an independent determinant of patient prognosis in advanced ovarian cancer. J Clin Oncol 18: 3775-37781, 2000.

54. Williams J, Lucas PC, Griffith KA, Choi M, Fogoros S, Hu YY and Liu JR: Expression of Bcl-xL in ovarian carcinoma is associated with chemoresistance and recurrent disease. Gynecol Oncol 96: 287-295, 2005

55. Reles A, Wen WH, Schmider A, Gee C, Runnebaum IB, Kilian U, Jones LA, El-Naggar A, Minguillon C, Schönborn I, Reich O, Kreienberg R, Lichtenegger W and Press MF: Correlation of p53 mutations with resistance to platinum-based chemotherapy and shortened survival in ovarian cancer. Clin Cancer Res 7: 2984-2997, 2001.

56. Takahashi M, Kigawa J, Minagawa Y, Itamochi H, Shimada M, Kamazawa S, Sato S, Akeshima R and Terakawa N: Sensitivity to paclitaxel is not related to p53-dependent apoptosis in ovarian cancer cells. Eur J Cancer 36: 1863-1868, 2000

57. Moll UM and Slade N: p63 and p73: roles in development and tumor formation. Mol Cancer Res 2: 371-386, 2004.

58. Urist MJ, Di Como CJ, Lu ML, Charytonowicz E, Verbel D, Crum CP, Ince TA, McKeon FD and Cordon-Cardo C: Loss of p63 expression is associated with tumor progression in bladder cancer. Am J Pathol 161: 1199-1206, 2002.

59. Reis-Filho JS, Milanezi F, Amendoeira I, Albergaria A and Schmitt FC: Distribution of p63, a novel myoepithelial marker, in fine-needle aspiration biopsies of the breast: an analysis of 82 samples. Cancer 99: 172-179, 2003.

60. Wang Y, Kringen P, Kristensen GB, Holm R, Baekelandt MM, Olivier M, Skomendal H, Hainaut P, Trope CG, Abeler VM, Nesland JM, Borresen-Dale AL and Helland A: Effect of codon 72 polymorphism (c. $215 \mathrm{G}>\mathrm{C}$, p.Arg72Pro) in combination with somatic sequence variants in the TP53 gene on survival in patients with advanced ovarian carcinoma. Hum Mutat 24: 21-34, 2004.

61. Liu S, Bishop WR and Liu M: Differential effects of cell cycle regulatory protein $\mathrm{p} 21 \mathrm{WAF} 1 / \mathrm{Cip} 1$ on apoptosis and sensitivity to cancer chemotherapy. Drug Resist Updat 6: 183-195, 2003.

62. Baekelandt M, Holm R, Trope CG, Nesland JM and Kristensen GB: Lack of independent prognostic significance of p21 and p27 expression in advanced ovarian cancer: an immunohistochemical study. Clin Cancer Res 5: 2848-2853, 1999.

63. Anttila MA, Kosma VM, Hongxiu J, Puolakka J, Juhola M, Saarikoski S and Syrjänen K: p21/WAF1 expression as related to $\mathrm{p} 53$, cell proliferation and prognosis in epithelial ovarian cancer. Br J Cancer 79: 1870-1878, 1999. 